\title{
EFFECT OF FURROW SPACING AND PHOSPHORUS FERTILIZATION TREATMENTS ON FABA BEAN YIELD, NUTRIENTS CONTENT AND SOME WATER RELATIONSHIPS
}

El-Saady, A. S. M. ; Gh. Sh. El-Atawy and R. H. Atia

Soils, Water and Environment Ins., Agric. Res. Center, Giza, Egypt.

\begin{abstract}
Two field trials were carried out at Sakha Agric. Res. St. farm during two successive winter seasons of 2007/2008 and 2008/2009, to assess the effect of planting methods and phosphorus fertilization treatments on faba bean yield, nutrient contents and some water relationships. Faba bean (Vicia faba L.) seeds var. Sakha 2 were planted on November in both seasons. Split plot design was used with four replicates. The main plots were assigned by two planting methods i.e. A: $120 \mathrm{~cm}$ furrow spacing with 4 planting rows per furrow and B:60 cm furrow spacing with 2 planting rows per furrow. The sub plots were assigned by four phosphorus treatments .e.1- application of $30 \mathrm{~kg} \mathrm{P}_{2} \mathrm{O}_{5} \mathrm{fed}^{-1}$ ( $\mathrm{ha}=2.4 \mathrm{fed}$.) as superphosphate $15.5 \% \mathrm{P}_{2} \mathrm{O}_{5}$ $\left(\mathrm{P}_{2} \mathrm{O}_{5}=2.29 \times \mathrm{P}\right)$, 2- completing the soil available phosphorus up to $30 \mathrm{~kg} \mathrm{P}_{2} \mathrm{O}_{5}$ fed ${ }^{-1}$ by superphosphate, 3- application of $15 \mathrm{~kg} \mathrm{P}_{2} \mathrm{O}_{5} \mathrm{fed}^{-1}$ in addition to inoculating faba bean seeds with phosphate dissolving bacteria and 4-application of $15 \mathrm{~kg} \mathrm{P}_{2} \mathrm{O}_{5}+$ inoculation with phosphate dissolving bacteria + spraying with cyanobacteria
\end{abstract} extraction.

The obtained results were summarized as follows:

- Planting methods high significantly affected seed yield in both seasons, the higher mean values of 1653.17 and $1766.75 \mathrm{~kg} \mathrm{fed}^{-1}$ were obtained with $60 \mathrm{~cm}$ furrow spacing in the first and second seasons, respectively.

- Planting method of $60 \mathrm{~cm}$ furrow spacing had the higher mean values of biomass $\left(6722.5\right.$ and $\left.7161.4 \mathrm{~kg} \mathrm{fed}^{-1}\right)$, higher 100 seed weight $(99.04$ and $101.56 \mathrm{~g})$ and the higher $\mathrm{N}$ content mean values (56.0 and $61.4 \mathrm{~kg} \mathrm{fed}^{-1}$ ).

- Planting method of $120 \mathrm{~cm}$ furrow spacing had the higher protein \% mean value in the second season (22.34\%), the higher seed P\% mean values $(0.55$ and $0.56 \%$ ) and the higher seed $P$ content values of 6.87 and $7.39 \mathrm{~kg} \mathrm{fed}^{-1}$ in the first and second seasons, respectively.

- Treatment of $15 \mathrm{~kg} \mathrm{P} \mathrm{P}_{5}+$ inoculation with phosphate dissolving bacteria had the highest seed yield, biomass yield, seed $\mathrm{N} \%, \mathrm{~N}$ content of the seeds, protein \% and $\mathrm{P} \%$.

- Treatment of $30 \mathrm{~kg} \mathrm{P}_{2} \mathrm{O}_{5}$ fed $^{-1}$ had the highest 100 seeds weight values and the highest residual available $P$ values in the soil after faba bean harvesting.

- Planting method of $60 \mathrm{~cm}$ furrow spacing had the higher water applied mean values (1596 and $1586 \mathrm{~m}^{3} \mathrm{fed}^{-1}$ ) and the higher water consumptive use mean values of 1380 and $1359 \mathrm{~m}^{3} \mathrm{fed}^{-1}$, while, $120 \mathrm{~cm}$ furrow spacing had the lower water applied mean values (1314 and $\left.1285 \mathrm{~m}^{3} \mathrm{fed}^{-1}\right)$ and the lower water consumptive use mean values of 1113 and $1069 \mathrm{~m}^{3} \mathrm{fed}^{-1}$ in the first and second season, respectively.

- The higher values of water productivity (WP) and productivity of irrigation water (PIW) were 1.24 and $1.30 \mathrm{~kg} \mathrm{~m}^{-3}$ and 1.04 and $1.11 \mathrm{~kg}$ of seeds $\mathrm{m}^{-3}$ were obtained from $60 \mathrm{~cm}$ furrow spacing in the $1^{\text {st }}$ and the $2^{\text {nd }}$ season, respectively.

Keywords: Faba bean, phosphorus fertilization, irrigation, water productivity. 


\section{INTRODUCTION}

Legumes usually require large amounts of phosphorus and their ability to utilize soil phosphate is often less pronounced than that of cereals and grasses (Guanawardena et al., 1992).

Shortage of phosphorus element can reduce legumes nodulation, $\mathrm{N}$ fixation and suppress seed yield (Abdel-Reheem et al., 1992).

Knowledge regarding the effects of cropping practices and fertilization management on the fate of $P$ applied to the soil is required to aid in the prediction of how such practices influence the quality and sustainability of the environment. Most Egyptian soils contain considerably high total phosphorus, yet the amount available for plant uptake is low even after fertilization with the super phosphate due to high $\mathrm{pH}$ soils, low organic matter content and calcium carbonate. In such case the two possible ways to increase plant available phosphorus are the use of phosphate solubilizing microorganisms or by decreasing soil $\mathrm{pH}$. A great attention has been paid to the use of phosphate dissolving microorganisms (Saber et al., 1983; Ibrahim et al., 1995; Abdul Wahid and Mehana, 1999; Hamissa et al., 2000 and Knany et al., 2004).

Knany et al. (2004) stated that, the highest faba bean seed and straw yields were obtained with $15 \mathrm{~kg} \mathrm{P}_{2} \mathrm{O}_{5}$ fed $^{-1}$. Inoculating faba bean seeds with phosphate dissolving bacteria achieved the highest hundred seeds weight and phosphorus uptake by the seeds and straw. Application of 50\% recommended dose of NPK as drip fertigation jointly with biofertigation and humic substances improved nutrient contents in soil ( $N, P, K, F e, M n$ and $\mathrm{Zn}$ ), plant growth nodule parameters, seed quality and fertilize use efficiency (kg seed $\mathrm{kg} \mathrm{NPK}^{-1}$ ) as well as nutritional assimilation (Selim et al., 2009).

Row spacing affect water relationships and faba bean yield and quality. Talal (2006) showed that, higher row spacing $(50-70 \mathrm{~cm})$ resulted in the greatest faba bean yield with a reduction at the narrow spacing.

The objectives of the present study are to investigate the effect of the residual soil phosphate, added phosphate, phosphate dissolving microorganisms on faba bean yield and chemical composition. As well as the effect of row spacing on faba bean yield and water relationships.

\section{MATERIALS AND METHODS}

Two field experiments were conducted at Sakha Agric. Res. Station farm ( $30^{\circ} 56^{\prime} \mathrm{N}$ latitude and $31^{\circ} 05^{\prime} \mathrm{E}$ longitude), Kafr El-Sheikh governorate, Egypt, during the two successive winter seasons 2007/2008 and 2008/2009. The recommended seed rate $\left(40 \mathrm{~kg} \mathrm{fed}^{-1}\right)$ of faba bean (Vicia faba L.) var Sakha-2 was planted on November in both seasons. Split plot design was used with four replicates. The main plots were assigned by two planting methods of $A: 120 \mathrm{~cm}$ furrow spacing with 4 planting rows per furrow, and B$60 \mathrm{~cm}$ furrow spacing with 2 planting rows per furrow. The sub-plots were randomly assigned with four phosphorus fertilization treatments of 1 : application of $30 \mathrm{~kg} \mathrm{P}_{2} \mathrm{O}_{5}$ fed $^{-1}\left(\mathrm{P}_{2} \mathrm{O}_{5}=2.29 \times \mathrm{P}\right)$, 2: completing the soil 
available phosphorus up to $30 \mathrm{~kg} \mathrm{P}_{2} \mathrm{O}_{5}$ fed $^{-1}$, 3: application of $15 \mathrm{~kg} \mathrm{P}_{2} \mathrm{O}_{5} \mathrm{fed}^{-1}$ in addition to inoculating faba bean seeds with phosphate dissolving bacteria (effective strain of Bacillus megatherium var. phosphaticum), and 4: application of $15 \mathrm{~kg} \mathrm{P}_{2} \mathrm{O}_{5}$ fed $^{-1}$ in addition to inoculating faba bean seeds with phosphate dissolving bacteria and spraying the plants (35 days from sowing) with cyanobacteria extract. Phosphorus was added as single superphosphate $15.5 \% \mathrm{P}_{2} \mathrm{O}_{5}$ during plots preparation as one dose. Effective nitrogen dose was added $\left(20 \mathrm{~kg} \mathrm{~N}^{-1} \mathrm{fed}^{-1}\right)$ as ammonium nitrate $33 \% \mathrm{~N}$ in one dose before the first irrigation. The other recommended agriculture practices were done. Some physical and chemical soil properties of the experimental field are presented in Table 1.

Available soil phosphorus was extracted by Olsen Method and determined colorimetrically by using spectrophotometer according to Jackson (1958). Available soil nitrogen was extracted by 1 normal $\mathrm{KCl}$ and determined by Kjeldahl method according to Black et al. (1965). Plant samples were fine ground and wet digested. Total nitrogen and total phosphorus were determined in the digested samples according to Jackson (1958). Protein \% was calculated by multiplying $\mathrm{N} \%$ x 6.25, FAO/WHO (1973).

Table 1: Some physical and chemical properties of the experimental field.

\begin{tabular}{|c|c|c|c|c|c|c|c|c|c|c|c|c|c|c|c|}
\hline \multirow{2}{*}{$\begin{array}{c}\text { Soil } \\
\text { depth }\end{array}$} & \multicolumn{3}{|c|}{$\begin{array}{l}\text { Particle size } \\
\text { distribution }\end{array}$} & \multirow{2}{*}{$\begin{array}{c}\text { Texture } \\
\text { class }\end{array}$} & \multirow{2}{*}{$\begin{array}{c}\text { Bulk } \\
\text { density } \\
\mathrm{kg} \mathrm{m}^{3}\end{array}$} & \multirow{2}{*}{$\begin{array}{c}\text { Field } \\
\text { capacity } \\
\%\end{array}$} & \multirow{2}{*}{$\begin{array}{c}\text { Per- } \\
\text { wilting } \\
\text { point } \\
\%\end{array}$} & \multirow{2}{*}{$\begin{array}{c}\text { Available } \\
\text { water } \%\end{array}$} & \multirow{2}{*}{$\mid \begin{array}{l}E C \\
d S \\
m^{-1}\end{array}$} & \multirow[t]{2}{*}{$\mathrm{pH}$} & \multirow{2}{*}{$\begin{array}{c}\text { EC of } \\
\text { ground } \\
\text { water } \\
\text { table }\end{array}$} & \multirow{2}{*}{$\begin{array}{c}\text { EC of } \\
\text { irrigation } \\
\text { water }\end{array}$} & \multicolumn{3}{|c|}{\begin{tabular}{|c|} 
Available \\
nutrients \\
mg kg $^{-1}$ \\
\end{tabular}} \\
\hline & $\begin{array}{c}\text { Sand } \\
\%\end{array}$ & \begin{tabular}{|c|} 
Silt \\
$\%$
\end{tabular} & $\begin{array}{c}\text { Clay } \\
\%\end{array}$ & & & & & & & & & & $\mathbf{N}$ & $\mathbf{P}$ & K \\
\hline \begin{tabular}{|c|c|}
$0-15$ & 1 \\
$15-30$ & 2 \\
$30-45$ & 2 \\
$45-60$ & 2
\end{tabular} & $\begin{array}{l}12.30 \\
20.20 \\
20.40 \\
21.10\end{array}$ & \begin{tabular}{|l|}
33.30 \\
34.20 \\
41.40 \\
41.50
\end{tabular} & $\begin{array}{l}54.40 \\
45.60 \\
38.20 \\
37.40\end{array}$ & $\begin{array}{l}\text { Clay } \\
\text { Clay } \\
\text { loam } \\
\text { Clay } \\
\text { loam }\end{array}$ & $\begin{array}{l}1260 \\
1210 \\
1290 \\
1380\end{array}$ & $\begin{array}{c}47.5 \\
39.87 \\
38.40 \\
36.39\end{array}$ & $\begin{array}{l}25.81 \\
21.66 \\
20.86 \\
19.78\end{array}$ & $\begin{array}{l}21.69 \\
16.21 \\
17.54 \\
16.61\end{array}$ & $\mid \begin{array}{l}2.46 \\
1.89 \\
2.39 \\
2.45\end{array}$ & $\begin{array}{l}7.81 \\
7.93 \\
7.96 \\
7.92\end{array}$ & $\begin{array}{c}2.3 \\
\mathrm{dSm}^{-1}\end{array}$ & $\begin{array}{c}0.64 \\
\mathrm{dSm}^{-1}\end{array}$ & 22 & 7 & 298 \\
\hline
\end{tabular}

EC was determined in soil paste extract and $\mathrm{pH}$ was determined in 1:2.5 soil water suspension according to the standard methods reported by Black et al. (1965)

Application of irrigation water was controlled by the constructed rectangular weir that furnished the site with steel gates of each plot. Rate of discharge was $16.54 \mathrm{~L} \mathrm{sec}^{-1}$. Water consumptive use or so called crop-water consumed (ETc) was calculated as stated by Hansen et al. (1979).

Where:

$$
\mathrm{SMD}=\mathrm{CU}=\frac{\theta_{2}-\theta_{2}}{100} \mathrm{Db} \times \mathrm{d} \times \mathrm{A} \mathrm{m}^{3} / \mathrm{fed}
$$

SMD = Soil moisture depletion in the effective root zone $=60 \mathrm{~cm}$

$\mathrm{CU}=$ Consumptive use of the growing plants

$\theta_{1}=$ Mean soil moisture percentage $(\mathrm{w} / \mathrm{w})$, before irrigation for the $60 \mathrm{~cm}$ soil depth.

$\theta_{2}=$ Mean soil moisture percentage $(\mathrm{w} / \mathrm{w})$ for the $60 \mathrm{~cm}$ soil depth, 48 hrs after irrigation (field capacity)

$\mathrm{Db}=$ Mean soil bulk density, $\mathrm{kg} \mathrm{m}^{-3}$ for the $60 \mathrm{~cm}$ soil depth 


\section{El-Saady, A. S. M. et al.}

D = Soil wetting depth i.e. effective root zone of $60 \mathrm{~cm}$.

$\mathrm{A}=$ Irrigated area, $\mathrm{m}^{2}$ (4200 $\mathrm{m}^{2}$ i.e. area of 1 feddan)

Water productivity (WP) was calculated according to Ali et al., (2007). $\mathrm{WP}=\mathrm{GY} / \mathrm{ET}$. Where: $\mathrm{WP}\left(\mathrm{kg}\right.$ seeds $\left.\mathrm{m}^{-3} \mathrm{WCU}\right), \mathrm{GY}=$ grain yield $\left(\mathrm{kg} \mathrm{fed}^{-1}\right)$ and $E T=$ total water consumption of the growing season $\left(\mathrm{m}^{3}\right.$ fed. $\left.{ }^{-1}\right)$. Productivity of irrigation water (PIW) was calculated as Ali et al., (2007).

$\mathrm{PIW}=\mathrm{GY} / \mathrm{I}$ Where: $\mathrm{GY}$ is grain yield $\left(\mathrm{kg} \mathrm{fed}^{-1}\right)$ and I is irrigation water applied $\left(\mathrm{m}^{3}\right.$ fed. $\left.^{-1}\right)$. Statistical analysis was made using MSTATC computer program.

\section{RESULTS AND DISCUSSION}

\section{Faba bean yield:}

\section{Seed yield:}

The seed yield is the most important part of faba bean production. Data presented in Table 2 showed that planting methods high significantly affected faba bean seed yield. The planting method of $60 \mathrm{~cm}$ furrow spacing with 2 planting row per furrow had the higher seed yield of 1653.17 and $1766.75 \mathrm{~kg} \mathrm{fed}^{-1}$ in the first and second seasons, respectively. The increase of the seed yield due to planting method equals 31.9 and $32 \%$ in the first and second seasons, respectively. This may be due to that the lower furrow spacing led to suitable plant density and vegetative growth. These results are in harmony with those obtained by Talal (2006) who found that the tested row spacing $(50-70 \mathrm{~cm})$ resulted in greatest faba bean seed yield.

On the other hand, no significant differences were obtained between the phosphorus treatments in the first season, while in the second season, there was significant effect due to the phosphorus treatments. The highest mean value of $1599.25 \mathrm{~kg}^{-1}$ was obtained with $15 \mathrm{~kg} \mathrm{P}_{2} \mathrm{O}_{5} \mathrm{fed}^{-1}+$ inoculation with phosphate dissolving bacteria + spraying with cyanobacteria. In this respect, no significant differences were detected between completing phosphorus in the soil to $30 \mathrm{~kg} \mathrm{P}_{2} \mathrm{O}_{5} \mathrm{fed}^{-1}, 15 \mathrm{~kg} \mathrm{P}_{2} \mathrm{O}_{5} \mathrm{fed}^{-1}+$ inoculation and $15 \mathrm{~kg} \mathrm{P}_{2} \mathrm{O}_{5}$ fed $^{-1}+$ inoculation + spraying with cyanobacteria. Data showed that the lowest mean values of 1367.44 and $1461.38 \mathrm{~kg}$ seeds were obtained with $30 \mathrm{~kg} \mathrm{P}_{2} \mathrm{O}_{5}$ fed $^{-1}$ treatment in the first and second seasons, respectively. These results could be enhanced by those obtained by El-Saady et al. (2007) who found that the lowest mean values of faba bean seed yield were recorded with $30 \mathrm{~kg} \mathrm{P}_{2} \mathrm{O}_{5}$ fed $^{-1}$ treatment at Sakha Agricultural Research station farm.

The previous results showed that phosphate dissolving bacteria increased the availability of the soil phosphate which led to increase faba bean seed yield. These results could be confirmed by those reported by Knany et al. (2004).

\section{Biomass yield:}

Data presented in Table (2) showed that furrow spacing, significantly affected faba bean biomass yield in the first season and highly significant in the second season. 
J. Soil Sci. and Agric. Eng., Mansoura Univ., Vol. 2 (5), May, 2011

2

601 


\section{El-Saady, A. S. M. et al.}

The traditional furrow $(60 \mathrm{~cm})$ had the higher biomass yield of 6722.5 and $7161.4 \mathrm{~kg} \mathrm{fed}^{-1}$ in the first and second seasons, respectively. This may be due to the amount of the irrigation water and nodulation which increased vegetative growth.

Significant differences due to phosphorus fertilization were detected in the first and the second seasons. Highest means values of 6705.25 and $6942.5 \mathrm{~kg} \mathrm{fed}^{-1}$ were observed with $15 \mathrm{~kg} \mathrm{P}_{2} \mathrm{O}_{5} \mathrm{fed}^{-1}+$ inoculation with phosphate dissolving bacteria in the first and the second seasons, respectively. This may be due to, that inoculation increased availability of soil phosphate. These results were in harmony with those reported by Hamissa et al., (2000) and Knany et al., (2004).

\subsection{0-seed weight:}

Data in Table 3 showed that furrow spacing high significantly affected 100 -seed weight in both seasons. The highest values of 99.04 and $101.56 \mathrm{~g}$ were obtained with $60 \mathrm{~cm}$ furrow spacing in the first and second seasons, respectively. This may be due to the amount of the irrigation water applied, where in the traditional furrows $(60 \mathrm{~cm})$ the irrigation water applied increased fertilizers solubility, nutrients availability, decreased salt concentration in the root zone, and increased plant growth and photosynthes.

Table 3: Effect of furrow spacing and phosphorus fertilization managements on 100 -seed weight $(\mathrm{g})$

\begin{tabular}{|c|c|c|c|c|c|c|c|c|c|}
\hline \multirow{3}{*}{ Treatments } & \multicolumn{5}{|c|}{ Season 2007/2008 } & \multicolumn{4}{|c|}{ Season 2008/2009 } \\
\hline & \multicolumn{2}{|c|}{ furrow spacing } & \multirow{2}{*}{\multicolumn{2}{|c|}{ T. mean }} & \multirow[t]{2}{*}{ Diff. } & \multicolumn{2}{|c|}{ furrow spacing } & \multirow{2}{*}{\begin{tabular}{|c|}
$\mathrm{T}$. \\
mean
\end{tabular}} & \multirow[t]{2}{*}{ Diff. } \\
\hline & $120 \mathrm{~cm}$ & $60 \mathrm{~cm}$ & & & & $120 \mathrm{~cm}$ & $60 \mathrm{~cm}$ & & \\
\hline $30 \mathrm{~kg} \mathrm{P}_{2} \mathrm{O}_{5}$ & $82.23 \mathrm{ab}$ & $104.3 \mathrm{a}$ & 93. & $26 a$ & -22.07 & $84.63 \mathrm{a}$ & $105.33 \mathrm{a}$ & $94.97 \mathrm{a}$ & -20.70 \\
\hline $\begin{array}{c}\text { Complete to } 30 \\
\mathrm{~kg} \mathrm{P}_{2} \mathrm{O}_{5}\end{array}$ & $83.13 a b$ & $94.18 \mathrm{a}$ & 88. & $65 \mathrm{a}$ & $\mid-11.05$ & $85.53 \mathrm{a}$ & $97.55 \mathrm{~b}$ & $91.54 \mathrm{a}$ & -12.03 \\
\hline $\begin{array}{l}15 \mathrm{~kg} \mathrm{P}_{2} \mathrm{O}_{5}+ \\
\text { inoc. }\end{array}$ & $87.08 \mathrm{a}$ & $98.82 \mathrm{a}$ & 92. & $95 \mathrm{a}$ & -11.75 & $88.70 \mathrm{a}$ & $101.55 \mathrm{ab}$ & $95.13 \mathrm{a}$ & -12.85 \\
\hline $\begin{array}{l}15 \mathrm{~kg} \mathrm{P}_{2} \mathrm{O}_{5}+ \\
\text { inoc. + cyano }\end{array}$ & $83.28 \mathrm{~b}$ & $98.88 \mathrm{a}$ & & 08 a & -25.60 & $81.60 \mathrm{a}$ & $101.80 \mathrm{ab}$ & $91.70 \mathrm{a}$ & -20.20 \\
\hline Mean & 81.43 & 99.04 & & & & 85.11 & 101.56 & 93.33 & \\
\hline F. test & & L.S.D. 0. & & L.S.L & 0.01 & & L.S.D. 0.0 & \begin{tabular}{l|l}
5 & L.S.I \\
\end{tabular} & D. 0.01 \\
\hline $\begin{array}{c}A \\
B \\
A B\end{array}$ & $\begin{array}{c}* * \\
N S \\
*\end{array}$ & $\begin{array}{c}- \\
- \\
10.8\end{array}$ & & & - & NS & $\begin{array}{c}- \\
- \\
7.48\end{array}$ & & - \\
\hline
\end{tabular}

In respect to phosphorus treatments, the highest 100-seed weight mean values $104.3 \mathrm{~g}$ in the first season, and $105.33 \mathrm{~g}$ in the second season, were obtained with $30 \mathrm{~kg} \mathrm{P}_{2} \mathrm{O}_{5}$ fed $^{-1}$ treatment under $60 \mathrm{~cm}$ furrow space. The obtained data showd the importance of phosphorus fertilization to faba bean crop. Similar results were reported by Bolland et al., (2000) who stated that phosphorus is the major nutrient for grain production of faba bean in neutral to alkaline soils.

\section{Chemical analysis of seeds:}

P treatments.

Nutrient status of faba bean plants as affected by furrow spacing and

\section{N\% of seeds:}

Data presented in Table 4 showed that no significant effects were detected in N\% due to planting methods during both seasons, while, there was 
high significant effect in N\% due to phosphorus fertilization treatments in the first and the second seasons.

The highest $\mathrm{N} \%$ mean values of $3.68 \%$ were obtained with $\left(15 \mathrm{~kg} \mathrm{P}_{2} \mathrm{O}_{5}+\right.$ inoculating with phosphate solubilizing bacteria) under $60 \mathrm{~cm}$ furrow spaces treatment in the two seasons. This may be due to the high soil pH in Egypt, presence of phosphate solubilizing bacteria led to more available phosphorus and the balance between $\mathrm{N}$ and $\mathrm{P}$ increased $\mathrm{N}$ uptake by faba bean. These results are in harmony with those obtained by Nassar et al., (2002) who found that application of some nutrients caused an increase in N, P, K and some micronutrients uptake in seeds and straw of broad bean.

$\mathrm{N}$ content of the seeds $\left(\mathrm{kg} \mathrm{fed}^{-1}\right)$ :

Data presented in Table 4 showed the nitrogen content of faba bean seeds in both seasons. In general, $60 \mathrm{~cm}$ furrow space had the higher $\mathrm{N}$ content in both seasons with average $56.0 \mathrm{~kg} \mathrm{fed}^{-1}$ comparing with $43.50 \mathrm{~kg}$ $\mathrm{fed}^{-1}$ in the first season and $61.4 \mathrm{~kg} \mathrm{fed}^{-1}$ comparing with $47.9 \mathrm{~kg} \mathrm{fed}^{-1}$ in the second season.

Phosphorus treatments, $15 \mathrm{~kg} \mathrm{P}_{2} \mathrm{O}_{5}+$ inoculation with phosphorus dissolving bacteria had the highest $\mathrm{N}$ content under $120 \mathrm{~cm}$ furrow spacing in both seasons 50.9 and $53.6 \mathrm{~kg} \mathrm{fed}^{-1}$ in the first and second seasons, respectively. Under $60 \mathrm{~cm}$ furrow space there was no significant differences between the phosphorus treatments, the highest $\mathrm{N}$ content values of 59.3 and $63.6 \mathrm{~kg} \mathrm{fed}^{-1}$ were observed with completing the soil available phosphorus to $30 \mathrm{~kg} \mathrm{P}_{2} \mathrm{O}_{5}$ fed $^{-1}$.

The significant response of $\mathrm{N}$ content to the high doses of phosphorus treatments under $120 \mathrm{~cm}$ furrow space, may be due to the less moisture in the root zone compared to $60 \mathrm{~cm}$ furrow space and the main way of phosphorus translocation from the soil to the root surface is by diffusion in presence of adequate moisture. Most of the phosphorus moves to the root by diffusion (Tisdal et al., 1985). Similar results were reported by Selim et al. (2009) who stated that application of $50 \%$ recommended dose of NPK jointly with biofertilization improved fertilizer use efficiency, as well s nutritional assimilation of cowpea.

Protein \% in the seed:

Data in Table 5 showed that furrow spacing had high effects of protein percentage in first and the second seasons, where $120 \mathrm{~cm}$ furrow space had the higher values of 21.61 and $22.34 \%$ in the first and second seasons, respectively . Under $120 \mathrm{~cm}$ furrow space no significant differences in the protein \% was found between the phosphorus treatments in both seasons. While, under $60 \mathrm{~cm}$ furrow space there was significant difference in the seed protein \% between phosphorus treatments in the two seasons. The highest values of 23.02 and $22.99 \%$ were obtained with $15 \mathrm{~kg} \mathrm{P}_{2} \mathrm{O}_{5}$ fed $^{-1}+$ inoculating with phosphorus solubilizing bacteria in the first and second seasons, respectively. While, the lowest values of 19.5 and 19.93 were recorded with $15 \mathrm{~kg} \mathrm{P}_{2} \mathrm{O}_{5}$ + inoculating + spraying with cyanobacteria in the first and second seasons, respectively. The difference in protein \% under $60 \mathrm{~cm}$ furrow space may be due to the effect of water amounts on phosphorus and nitrogen absorption. 
El-Saady, A. S. M. et al.

4-5 


\section{Phosphorus \% and phosphorus content:}

Data in Table 6 showed that there were significant differences in $\mathrm{P} \%$ due to planting methods in both seasons. $120 \mathrm{~cm}$ furrow space had the higher $\mathrm{P} \%$ of 0.55 and $0.56 \%$ in the first and second seasons, respectively. Phosphorus content in faba bean seed had the same trend in the first season, where $120 \mathrm{~cm}$ furrow space had the higher P-content values of 6.87 in the first season and the higher value of $7.69 \mathrm{~kg} \mathrm{fed}^{-1}$ was obtained with 60 $\mathrm{cm}$ space, in the second season.

In respect to phosphorus treatments, and its effects on $\mathrm{P} \%$ and $\mathrm{P}$ content. Under $120 \mathrm{~cm}$ furrow space, there were highly significantly effects of phosphorus treatments on $\mathrm{P} \%$ and $\mathrm{P}$-content in both seasons. the highest $\mathrm{P} \%$ values of 0.68 and $0.63 \%$ were obtained with $15 \mathrm{~kg} \mathrm{P}_{2} \mathrm{O}_{5} \mathrm{fed}^{-1}+$ inoculating with phosphorus solubilizing bacteria in the first and second seasons, respectively. Phosphorus content had the same trend in the first season, where the highest values of 9.5 was recorded with the same treatment. Under $60 \mathrm{~cm}$ furrow space, no significant differences were detected between the phosphorus treatments in both seasons except $\mathrm{P} \%$ in the second season, where, there was highly significant effect and the highest value of $0.5 \%$ was observed with the same treatment. Similar results on cowpea were reported by Knany et al.(2002) who stated that phosphorus placement increased phosphorus percentage of cowpea seeds up to $15 \mathrm{~kg}$ $\mathrm{P}_{2} \mathrm{O}_{5}$ fed $^{-1}$, but no clear increase was due to increasing phosphorus placement from 15 to $30 \mathrm{~kg} \mathrm{P}_{2} \mathrm{O}_{5}$ fed $^{-1}$, and Masoud et al. (2007) stated that the narrow spaces between plants $(15 \mathrm{~cm})$ had the lowest phosphorus percentage in faba bean seeds.

\section{Residual $\mathbf{N}$ and $\mathbf{P}$ in the soil:}

Data in Table 7 showed that planting methods had no significant effects of available nitrogen in the soil after faba bean harvesting in both seasons. While phosphorus treatments highly significant affected the residual available- $\mathrm{N}$ in the soil after faba bean harvesting under $60 \mathrm{~cm}$ furrow space, only in both seasons.

The highest available $\mathrm{N}$ value of 35 and $35.25 \mathrm{mg} \mathrm{kg}^{-1}$ in the first and second seasons, respectively, were obtained with completing the available phosphorus in the soil to $30 \mathrm{~kg} \mathrm{P}_{2} \mathrm{O}_{5} \mathrm{fed}^{-1}$ treatment. Residual available phosphorus high significantly affected by planting methods. The higher residual phosphorus values of 15.68 and $15.23 \mathrm{mg} \mathrm{kg}^{-1}$ were obtained with $60 \mathrm{~cm}$ furrow space in the first and second seasons, respectively. 


\section{El-Saady, A. S. M. et al.}

6-7 
In respect to phosphorus treatments and its effects on the residual available phosphorus, the highest residual available phosphorus of $16.25,17.4,16.6$ and $16.8 \mathrm{mg} \mathrm{kg}^{-1}$ soil were obtained with $30 \mathrm{~kg} \mathrm{P}_{2} \mathrm{O}_{5}$ fed $^{-1}$ under the two planting methods in the first and second seasons, respectively. This may be due to the huge amount of $30 \mathrm{~kg} \mathrm{P}_{2} \mathrm{O}_{5}$ rather than the crop needs, some of this amount still available in the soil specially in presence of different species of the microorganisms in the rhizosphere and the root zone. These results are in harmony with those obtained by Knany et al. (2002). Water relationships:

\section{a- Water applied:}

Data presented in Table 8 showed that furrow spacing clearly affected the water applied. $120 \mathrm{~cm}$ furrow space had the lower water applied values of 1314 and $1285 \mathrm{~m}^{3} \mathrm{fed}^{-1}$ in the first and second seasons, respectively. The water saving values were 17.63 and $18.95 \%$ in the first and second seasons, respectively. Phosphorus treatments had no significant effects on water applied in both seasons, except the second season under $120 \mathrm{~cm}$ furrow space as a planting method. The highest value of $1291 \mathrm{~m}^{3} \mathrm{fed}$ ${ }^{1}$ was recorded with $15 \mathrm{~kg} \mathrm{P}_{2} \mathrm{O}_{5}$ fed $^{-1}+$ inoculation + cyanobacteria spraying. While the lowest value of $1281 \mathrm{~m}^{3}$ fed $^{-1}$ was obtained with $30 \mathrm{~kg} \mathrm{P}_{2} \mathrm{O}_{5} \mathrm{fed}^{-1}$. This may be due to the differences of the vegetative growth and faba bean biomass which affected evapotranspiration.

Table 8: Effect of furrow spacing and phosphorus treatments on water applied and water consumptive use by faba bean $\left(\mathrm{m}^{3} \mathrm{fed}^{-1}\right)$

\begin{tabular}{|c|c|c|c|c|c|c|c|c|c|c|c|c|}
\hline \multirow{4}{*}{ Treatments } & \multicolumn{6}{|c|}{ Season $2007 / 2008$} & \multicolumn{6}{|c|}{ Season $2008 / 2009$} \\
\hline & \multicolumn{3}{|c|}{ Water applied } & \multicolumn{3}{|c|}{\begin{tabular}{|c|} 
Water \\
consumptive use
\end{tabular}} & \multicolumn{3}{|c|}{ Water applied } & \multicolumn{3}{|c|}{$\begin{array}{c}\text { Water } \\
\text { consumptive use }\end{array}$} \\
\hline & \multicolumn{6}{|c|}{ Planting methods (furrow spacing) } & \multicolumn{6}{|c|}{ Planting methods (furrow spacing) } \\
\hline & $\begin{array}{l}120 \\
\mathrm{~cm}\end{array}$ & $\begin{array}{l}60 \\
\mathrm{~cm}\end{array}$ & Mean & $\begin{array}{l}120 \\
\mathrm{~cm}\end{array}$ & $\begin{array}{l}60 \\
\mathrm{~cm}\end{array}$ & Mean & $\begin{array}{l}120 \\
\mathrm{~cm}\end{array}$ & $\begin{array}{l}60 \\
\mathrm{~cm}\end{array}$ & Mean & $\begin{array}{l}120 \\
\mathrm{~cm}\end{array}$ & $\begin{array}{l}60 \\
\mathrm{~cm}\end{array}$ & Mean \\
\hline $30 \mathrm{~kg} \mathrm{P}_{2} \mathrm{O}_{5}$ & $1311 \mathrm{a}$ & $1596 a$ & $1454 a$ & $1114 \mathrm{a}$ & $1385 \mathrm{a}$ & & $1281 \mathrm{~b}$ & $1586 \mathrm{a}$ & & $1077 \mathrm{a}$ & $1363 \mathrm{a}$ & 1220 \\
\hline $\begin{array}{c}\text { Complete to } 30 \\
\mathrm{~kg} \mathrm{P} \mathrm{P}_{2} \mathrm{O}_{5}\end{array}$ & $1312 \mathrm{a}$ & 1595 a & $1453 a$ & $1111 \mathrm{a}$ & $1380 \mathrm{a}$ & $1246 \mathrm{a}$ & $1285 a b$ & $1586 a$ & $6 \mathrm{a}$ & $1072 \mathrm{a}$ & $1353 \mathrm{a}$ & $1212 \mathrm{a}$ \\
\hline $\begin{array}{l}15 \mathrm{~kg} \mathrm{P}_{2} \mathrm{O}_{5}+ \\
\text { inoc. }\end{array}$ & $1317 \mathrm{a}$ & $1595 \mathrm{a}$ & $1456 a$ & $1113 \mathrm{a}$ & $1375 \mathrm{a}$ & $1244 \mathrm{a}$ & $1284 a b$ & $1585 a$ & $1434 \mathrm{a}$ & $1053 \mathrm{a}$ & $1368 \mathrm{a}$ & $1210 \mathrm{a}$ \\
\hline $\begin{array}{l}15 \mathrm{~kg} \mathrm{P} \mathrm{P}_{2} \mathrm{O}_{5}+ \\
\text { inoc. + cyano }\end{array}$ & $1317 \mathrm{a}$ & $1597 \mathrm{a}$ & $1457 a$ & $1113 \mathrm{a}$ & $1380 \mathrm{a}$ & $1247 a$ & $1291 \mathrm{a}$ & $1586 \mathrm{a}$ & $1439 \mathrm{a}$ & 1072 & $1355 \mathrm{a}$ & $1214 \mathrm{a}$ \\
\hline Mean & 1314 & 1596 & & 1113 & 1380 & & 1285 & 1586 & & 1069 & 1359 & \\
\hline
\end{tabular}

\section{b- Water consumptive use:}

Water consumptive use had the same trend of water applied, where there was clear effect of planting methods on water consumptive use during both seasons. The higher values were recorded with $60 \mathrm{~cm}$ furrow space in both seasons $\left(1380\right.$ and $\left.1359 \mathrm{~m}^{3} \mathrm{fed}^{-1}\right)$. No significant effects were detected on water consumptive use due to phosphorus treatments.

\section{c. Water productivity (WP)}

Water productivity expressed in $\mathrm{kg}$ of seeds for $\mathrm{m}^{-3}$ of water consumed and productivity of irrigation water(PIW) in $\mathrm{Kg}$ seed $\mathrm{m}^{-3}$ of irrigation water applied are presented in Table 9. 


\section{El-Saady, A. S. M. et al.}

The obtained results showed that WP was increased as the irrigation water applied increased, $60 \mathrm{~cm}$ furrow space had the higher values of WP to be 1.24 and $1.30 \mathrm{~kg}$ of seeds $\mathrm{m}^{-3}$ of water consumed, while the lower one was 1.13 and $1.25 \mathrm{~kg}$ seed yield $\mathrm{m}^{-3}$ of water consumed, resulted from 120 $\mathrm{cm}$ furrow space in the $1^{\text {st }}$ and $2^{\text {nd }}$ season, respectively.

Table 9:Water productivity (WP) in $\mathrm{Kg}$ seeds $\mathrm{m}^{-3}$ of water consumptive use and productivity of irrigation water (PIW) in $\mathrm{Kg} \mathrm{m}^{-3}$ of irrigation water applied in 2009and 2010 seasons.

\begin{tabular}{|c|c|c|c|c|c|c|c|c|c|c|c|c|}
\hline \multirow{4}{*}{ Treatments } & \multicolumn{6}{|c|}{ Water productivity } & \multicolumn{6}{|c|}{ productivity of irrigation water } \\
\hline & \multicolumn{6}{|c|}{ Planting methods (furrow spacing) } & \multicolumn{6}{|c|}{ Planting methods (furrow spacing) } \\
\hline & $\begin{array}{l}120 \\
\mathrm{~cm}\end{array}$ & $\begin{array}{l}60 \\
\mathrm{~cm}\end{array}$ & Mean & $\begin{array}{l}120 \\
\mathrm{~cm}\end{array}$ & $\begin{array}{l}60 \\
\mathrm{~cm}\end{array}$ & Mean & $\begin{array}{l}120 \\
\mathrm{~cm}\end{array}$ & $\begin{array}{l}60 \\
\mathrm{~cm}\end{array}$ & Mean & $\begin{array}{l}120 \\
\mathrm{~cm}\end{array}$ & $\begin{array}{l}60 \\
\mathrm{~cm}\end{array}$ & $A$ \\
\hline & \multicolumn{3}{|c|}{$2007 / 2008$ season } & \multicolumn{3}{|c|}{ 2008/2009 season } & \multicolumn{6}{|c|}{$2007 / 2008$ season $2008 / 2009$ season } \\
\hline $30 \mathrm{~kg} \mathrm{P} \mathrm{P}_{5}$ & 1.00 & 1.17 & 1.10 & 1.10 & 1.27 & 1.20 & 0.849 & 1.02 & 0.94 & 0.93 & 1.10 & 1.02 \\
\hline $\begin{array}{c}\text { Complete to } 30 \\
\mathrm{~kg} \mathrm{P} \mathrm{P}_{2} \mathrm{O}_{5}\end{array}$ & 1.07 & 1.26 & 1.18 & 1.23 & 1.39 & 1.32 & 0.91 & 1.09 & 1.01 & 1.03 & 1.18 & 1.11 \\
\hline $\begin{array}{c}15 \mathrm{~kg} \mathrm{P}_{2} \mathrm{O}_{5}+ \\
\text { inoc. }\end{array}$ & 1.25 & 1.10 & 1.17 & 1.39 & 1.20 & 1.28 & 1.06 & 0.95 & 1.00 & 1.14 & 1.04 & 1.08 \\
\hline $\begin{array}{l}15 \mathrm{~kg} \mathrm{P} \mathrm{P}_{2} \mathrm{O}_{5}+ \\
\text { inoc. + cyano }\end{array}$ & 1.18 & 1.24 & 1.22 & 1.29 & 1.34 & 1.32 & 1.00 & 1.08 & 1.04 & $1.07 \mathrm{~b}$ & 1.15 & 1.11 \\
\hline Mean & 1.13 & 1.24 & & 1.25 & 1.30 & & 0.96 & 1.04 & & 1.04 & 1.11 & \\
\hline
\end{tabular}

\section{.Productivity of irrigation water (PIW)}

Results presented in Table 9 indicated that PIW was increased as the irrigation water applied increased, $60 \mathrm{~cm}$ furrow space had the higher values of WP to be 1.04 and $1.11 \mathrm{~kg}$ of seeds $\mathrm{m}^{-3}$ of water consumed, while the lower one was 0.96 and $1.04 \mathrm{~kg}$ seed yield $\mathrm{m}^{-3}$ of water consumed, resulted from $120 \mathrm{~cm}$ furrow space in the $1^{\text {st }}$ and $2^{\text {nd }}$ season, respectively.

\section{REFERENCES}

Abdel-Reheem, M.A.; E.N. Gendy, R.M. El-Awady and K.S. El-Halawany (1992). Interaction effect between phosphorus and manganese on broad bean plants in Alluvial soil. Egypt. J. Soil Sci. 32(2): 227-237.

Abdul-Wahid, O.A. and T.A. Mehana (1999). Influence of phosphate dissolving fungi on the yield and phosphorus uptake by wheat and faba bean plants. Recent Technologies in Agric. Proc. of the $1^{\text {st }}$ Congress, Cairo Univ., Fac. Agric., 26-29 Nov. 1999, Vol. N. pp. 794-803.

Ali, M. H.; M. R. Hoque; A. A. Hassan and A. Khair (2007). Effects of deficit irrigation on yield, water productivity, and economic returns of wheat. Agricultural Water Management 92 (3): 151-161.

Black, C.A.; D.D. Evans; J.L. White; L.E. Ensuminger and F.F. Clark (1965). Methods of Soil Analysis. Am. Soc. Agron. Inc. Publc. Madison, Wisconsin.

Bolland, M.D.A.; K.H.A. Siddique and RF. Brennan (2000). Grain yield response of faba bean (Vicia faba L.) to application of fertilizer phosphorus and zinc. Australian Journal of Experimental Agric. 40(6): 849-857. 
El-saady, A.S.M.; R.H. Atia; R.E. Knany and N.I. Talha (2007). Response of faba bean to foliar application of copper and molybdenum under phosphorus fertilization levels. J. Agric. Sci. Mansoura Uni., 32 (1): 747-757.

FAO/WHO (1973) Committee on Energy and Protein Requirements.

Guanawardena, S.F.B.N.; S.K.A. Danso and F. Zapata (1992). Phosphorus requirements and nitrogen accumulation by three mung bean (Vigna radiata L. Welzek) cultivars. Plant and Soil. 147: 267-274.

Hamissa, A.M.; F.M. Hammoda and R.E. Knany (2000). Response of nodulated faba bean crop to phosphate solubilizing bacteria under phosphorus fertilization and copper foliar spray application. J. Agric. Sci. Mansoura Univ. 25(5): 2995-3007.

Hansen, V.W.; O.W. Israelsen and Q.E. Stringharm (1979). Irrigation Principles and Practices. $4^{\text {th }}$ Edition, John Willey and Sons, 1979.

Ibrahim, A.N;; A.H.H. Mahmoud and M.B. El-Katkat (1995). In vivo, study the effect of phosphate solubilizing bacteria and super phosphate on the production of broad bean and wheat plants. Menofia Journal of Agric. Res.., 20: 2361-2377.

Jackson, M.L. (1958). Soil Chemical Analysis. Prentice-Hall, Inc., Englewood Cliffs, New York, USA.

Knany, R.E.; A.M. Masoud and A.M. Kansouh (2002). Impact of phosphorus fertilization and some micronutrients spraying on seed yield and quality of new cowpea cultivars. J. Agric. Res. Tanta Univ. Special Issue for 2ndn Inter. Conf. Hort.. Sci. 1012 Sept. 2202. Kafr El-Sheikh, Tanta Univ., Egypt. pp. 1035-1045.

Knany, R.W.; A.M. Masoud and Y.B. El-Waraky (2004). Comparative study between biofertilization and sulphur on availability of added phosphorus to faba bean plants under high $\mathrm{pH}$ soil conditions. J. Agric. Sci. Mansoura Univ., 29(8): 4801-4809.

Masoud, A.M.; Y.B.; El-Waraky and R.E. Knany (2007). Effect of some agricultural practices on yield, protein and nitrate accumulation of the green and dry broadbean seeds. J. Agric. Sci. Mansoura Univ., 32(9): 7641-7651.

Nassar, K.E.; A.O. Osman; M.H. El-Kholy and Madiha M. Badran (2002). Effect of seed coating with some micronutrients on faba bean. Egypt Journal, Soil Sci., 42(3): 363-381.

Saber, M.S.M.; H.K. Abd El-Maksoud and M.A. Khalafalla (1983). The use of phosphorus dissolving bacteria for increasing phosphorus uptake and yield of Vicia faba L. cultivated in a calcareous soil. Egyptian Journal of Microbiology, Special Issue pp. 41-46.

Selim, E.M.; A.M. El-Ghamry and T.M. El-Zehery (2009). Integrated impacts of biofertigation and humic substances on nutrient contents of cowpea grown on newly reclaimed soils. J. Agric. Sci. Mansoura Univ., 34(7): 8547-8558.

Talal, T. (2006). Impacts of row spacing of faba bean $L$ growth under Mediterranean rain-fed conditions. Journal of Agronomy, 5(3): 527-532.

Tisdal, S. L.; W. L. Nelson and J. D. Beaton (1985). Soil Fertility and Fertilizers $4^{\text {th }}$ Edition Macmillan Publ. Co., New York. 
El-Saady, A. S. M. et al.

تأثير طرق الزراعة ومعاملات التسميذ الفوسفاتي على محصول الفول البلدي

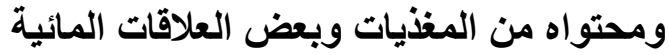

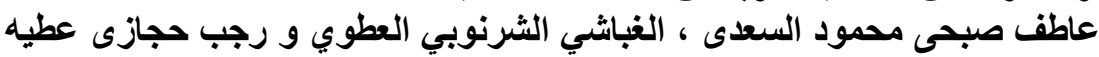

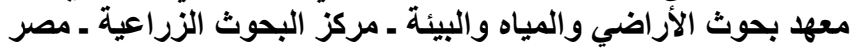

نفذت تجربتان حقليتان بمزرعة محطة البحوث الزراعية بسخا خلال الموسمين الثتويين

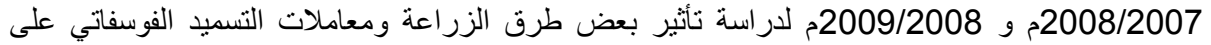

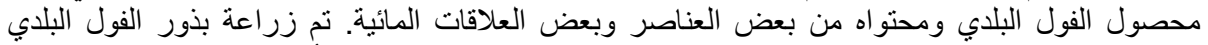

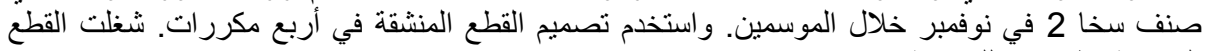

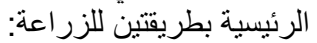

الزراعة على خطوط عرضهاعها 120سم حيث تم زر اعة أربعة صفوف نباتية عليها.

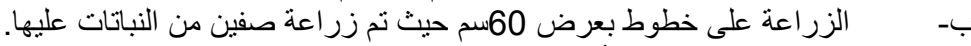
وشغلت القطع الثقية بأربع معاملات للتسميد الفوسفاتي:

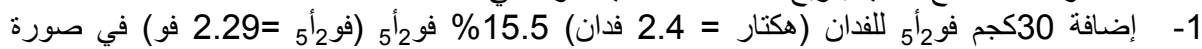

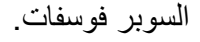

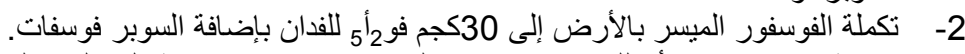

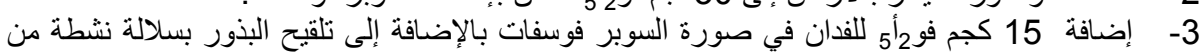
البكتريا المذيبة للفوسفات.

4- إضافة 15كجم فو أم للفدان + التلقيح بالبكتريا المذيبة للفوسفات + الرش بمستخلص السيانوبكتريا ويمكن تلخيص النتائج المتحصل عليها كالأتي: • أعطت طرق الزراعة فروقا عالية المعنوية في محصول البذور في الموسمين حيث كانت أعلى قيما

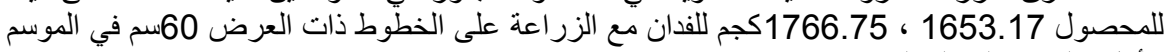

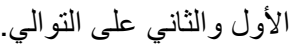

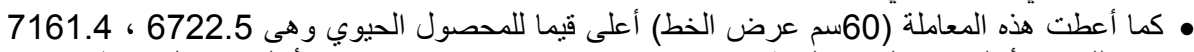

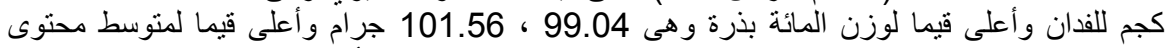

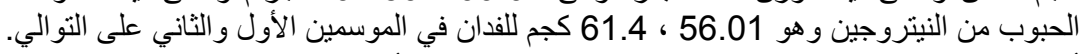

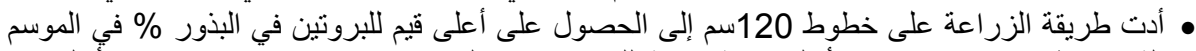

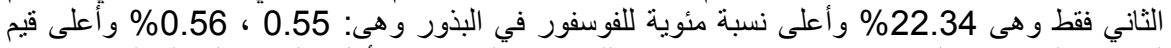

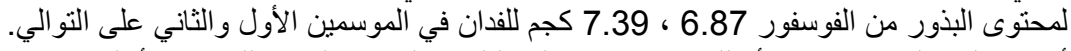

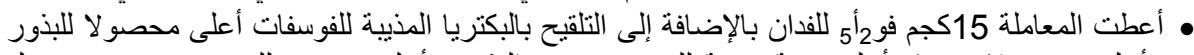

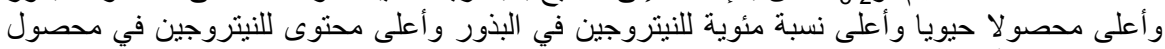

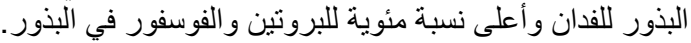

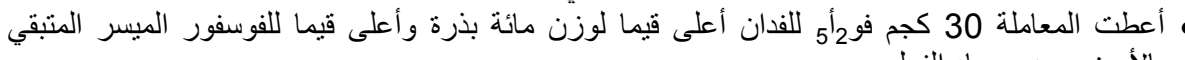

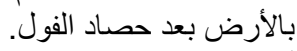

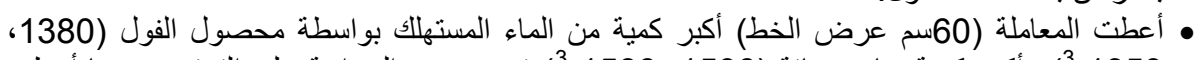

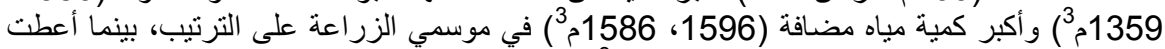

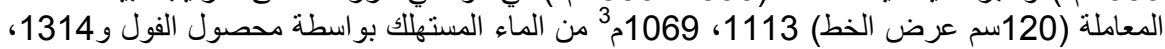
ه 1285م3 ماء مضافا في موسمي الزر اعة على الترتيب.

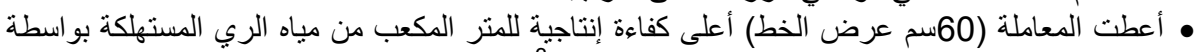

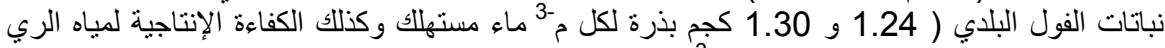
المضافة (1.04 و 1.11 كجم بذرة لكل م-3 ماء مضاف ) في موسمي الزر ماعة على التو الئي.

قام بتحكيم البحث

كلية الزراعة - جامعة المنصورة كلية الزراعة - جامعة كفر الثيخ

أ.د / خالد حسن الحامدى اليد أ.د / صابر عبده جاهين الد حاهن 
J. Soil Sci. and Agric. Eng., Mansoura Univ., Vol. 2 (5), May, 2011 
J. Soil Sci. and Agric. Eng., Mansoura Univ., Vol. 2 (5): 597 - 610, 2011

Table 2: Effect of planting methods (furrow spacing) and phosphorus fertilization treatments on faba bean seed yield and biomass yield $\mathrm{kg} \mathrm{fed}^{-1}$.

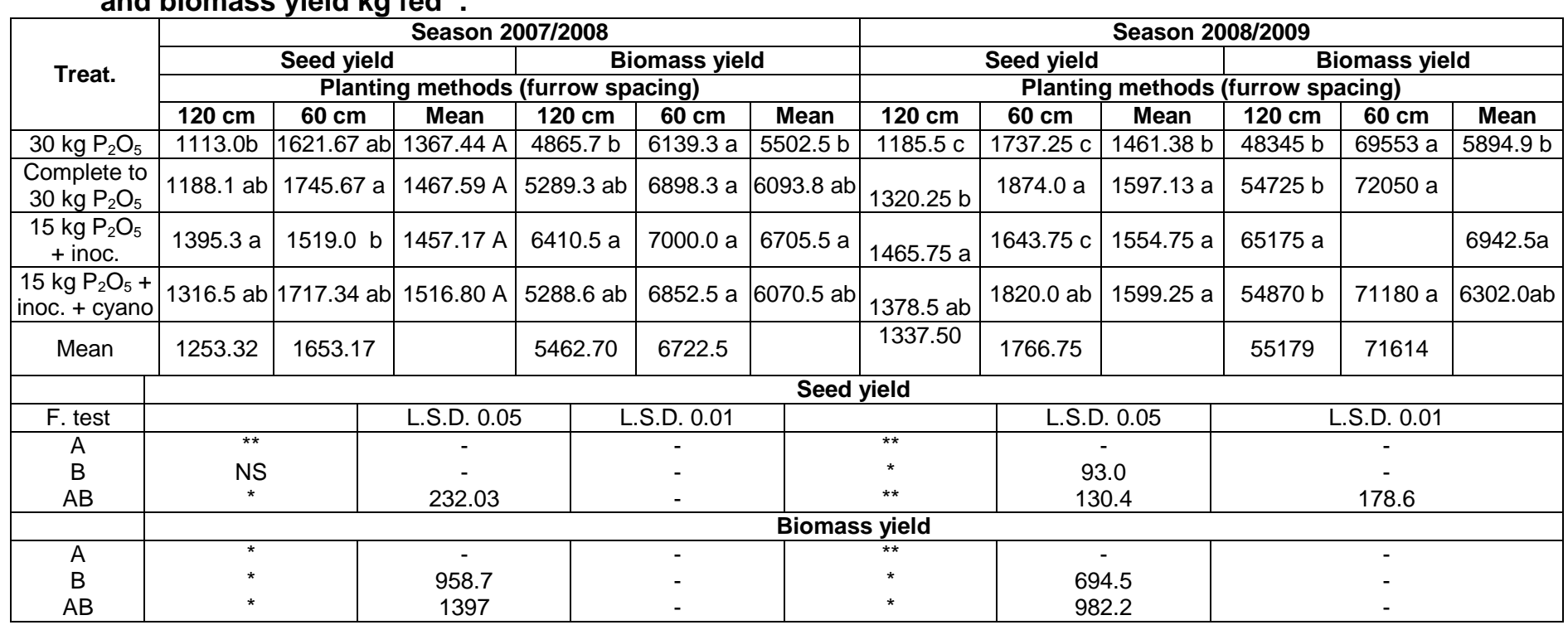


J. Soil Sci. and Agric. Eng., Mansoura Univ., Vol. 2 (5), May, 2011

Table 4:Effect of furrow spacing and phosphorus fertilization treatments on $\mathrm{N} \%$ and $\mathrm{N}$-content of the faba bean seeds $\mathrm{kg} \mathrm{fed}^{-1}$.

\begin{tabular}{|c|c|c|c|c|c|c|c|c|c|c|c|c|}
\hline \multirow{4}{*}{ Treatments } & \multicolumn{6}{|c|}{ Season $2007 / 2008$} & \multicolumn{6}{|c|}{ Season $2008 / 2009$} \\
\hline & \multicolumn{3}{|c|}{$\mathrm{N} \%$} & \multirow{2}{*}{\multicolumn{3}{|c|}{$\begin{array}{l}\text { N-content } \\
\text { (furrow spacing) }\end{array}$}} & \multirow{2}{*}{\multicolumn{3}{|c|}{ N\% }} & \multicolumn{3}{|c|}{ N-content } \\
\hline & \multicolumn{3}{|c|}{ Planting methods (furrow spacing) } & & & & \multicolumn{5}{|c|}{ Planting methods (furrow spacing) } & \\
\hline & $120 \mathrm{~cm}$ & $60 \mathrm{~cm}$ & Mean & $120 \mathrm{~cm}$ & $60 \mathrm{~cm}$ & Mean & $120 \mathrm{~cm}$ & $60 \mathrm{~cm}$ & Mean & $120 \mathrm{~cm}$ & $60 \mathrm{~cm}$ & Mean \\
\hline $30 \mathrm{~kg} \mathrm{P}_{2} \mathrm{O}_{5}$ & $3.30 \mathrm{a}$ & $3.46 \mathrm{ab}$ & $3.38 a b$ & $36.6 \mathrm{c}$ & $55.2 \mathrm{a}$ & $45.9 \mathrm{~b}$ & $3.58 \mathrm{a}$ & $3.56 \mathrm{a}$ & $3.57 \mathrm{ab}$ & $42.5 \mathrm{c}$ & $63.5 \mathrm{a}$ & $53 \mathrm{~b}$ \\
\hline $\begin{array}{c}\text { Complete to } 30 \mathrm{~kg} \\
\mathrm{P}_{2} \mathrm{O}_{5}\end{array}$ & $3.50 \mathrm{a}$ & $3.38 \mathrm{ab}$ & $3.44 a b$ & $41.5 \mathrm{bc}$ & $59.3 \mathrm{a}$ & $50.4 \mathrm{ab}$ & $3.56 \mathrm{a}$ & $3.40 \mathrm{~b}$ & $3.48 \mathrm{bc}$ & $47.1 \mathrm{bc}$ & $63.6 \mathrm{a}$ & $55.3 a b$ \\
\hline $15 \mathrm{~kg} \mathrm{P} \mathrm{P}_{2} \mathrm{O}_{5}+$ inoc. & $3.66 \mathrm{a}$ & $3.68 \mathrm{a}$ & $3.67 a$ & $50.9 \mathrm{a}$ & $56.0 \mathrm{a}$ & $53.4 \mathrm{a}$ & $3.66 \mathrm{a}$ & $3.68 \mathrm{a}$ & $3.67 \mathrm{a}$ & $53.6 \mathrm{a}$ & $60.5 \mathrm{a}$ & $57.1 \mathrm{a}$ \\
\hline $\begin{array}{c}15 \mathrm{~kg} \mathrm{P}_{2} \mathrm{O}_{5}+\text { inoc. }+ \\
\text { cyano }\end{array}$ & $3.40 \mathrm{a}$ & $3.12 b$ & $3.26 \mathrm{~b}$ & $45.0 \mathrm{ab}$ & $53.6 \mathrm{a}$ & $\begin{array}{c}49.3 \\
a b\end{array}$ & $3.50 \mathrm{a}$ & $3.19 \mathrm{~b}$ & $3.35 \mathrm{c}$ & $48.3 \mathrm{~b}$ & $58.1 \mathrm{a}$ & $53.2 \mathrm{~b}$ \\
\hline \multirow[t]{2}{*}{ Mean } & 3.46 & 3.41 & & 43.5 & 56.0 & & 3.57 & 3.48 & & 47.9 & 61.4 & \\
\hline & \multicolumn{12}{|c|}{$\mathbf{N} \%$} \\
\hline F. test & & & \multicolumn{2}{|c|}{ L.S.D. 0.05} & \multicolumn{2}{|c|}{ L.S.D. 0.01} & & & \multicolumn{2}{|c|}{ L.S.D. 0.05} & \multicolumn{2}{|c|}{ L.S.D. 0.01} \\
\hline $\begin{array}{l}A \\
B\end{array}$ & \multicolumn{2}{|c|}{ NS } & \multirow{2}{*}{\multicolumn{2}{|c|}{0.34}} & \multirow{2}{*}{\multicolumn{2}{|c|}{ - }} & \multicolumn{2}{|c|}{ NS } & \multirow{2}{*}{\multicolumn{2}{|c|}{0.172}} & \multirow{2}{*}{\multicolumn{2}{|c|}{0.236}} \\
\hline \multirow{2}{*}{$A B$} & \multicolumn{2}{|c|}{$\stackrel{*}{N S}$} & & & & & \multicolumn{2}{|c|}{ NS } & & & & \\
\hline & \multicolumn{6}{|c|}{$\mathrm{cc}$} & tent & & & & & \\
\hline A & \multicolumn{2}{|c|}{ ** } & \multirow{2}{*}{\multicolumn{2}{|c|}{5.80}} & \multirow{2}{*}{\multicolumn{2}{|c|}{ - }} & \multirow{2}{*}{\multicolumn{2}{|c|}{ ** }} & \multirow{2}{*}{\multicolumn{2}{|c|}{$\begin{array}{l}3.68 \\
5.21\end{array}$}} & \multicolumn{2}{|c|}{ - } \\
\hline $\begin{array}{c}B \\
A B\end{array}$ & \multirow{2}{*}{\multicolumn{2}{|c|}{ NS }} & & & & & & & & & & \\
\hline & & & \multicolumn{2}{|c|}{-} & \multicolumn{2}{|c|}{ - } & & & & & & \\
\hline
\end{tabular}

Table 5: Protein \% in the seed as affected by furrow spacing and phosphorus treatments.

\begin{tabular}{|c|c|c|c|c|c|c|c|c|}
\hline \multirow{3}{*}{ Treatments } & \multicolumn{4}{|c|}{ Season $2007 / 2008$} & \multicolumn{4}{|c|}{ Season 2008/2009 } \\
\hline & \multicolumn{2}{|c|}{ Planting methods } & \multirow{2}{*}{ T. mean } & \multirow{2}{*}{ Diff. } & \multicolumn{2}{|c|}{ Planting methods } & \multirow{2}{*}{ T. mean } & \multirow{2}{*}{ Diff. } \\
\hline & $120 \mathrm{~cm}$ & $60 \mathrm{~cm}$ & & & $120 \mathrm{~cm}$ & $60 \mathrm{~cm}$ & & \\
\hline $30 \mathrm{~kg} \mathrm{P}_{2} \mathrm{O}_{5}$ & $20.60 a$ & $21.63 \mathrm{ab}$ & $21.11 \mathrm{ab}$ & -1.03 & $22.40 \mathrm{a}$ & $22.86 \mathrm{a}$ & $22.63 \mathrm{ab}$ & -0.46 \\
\hline $\begin{array}{c}\text { Complete to } 30 \mathrm{~kg} \\
\mathrm{P}_{2} \mathrm{O}_{5}\end{array}$ & $21.90 \mathrm{a}$ & $21.13 \mathrm{ab}$ & $21.51 \mathrm{ab}$ & 0.77 & $22.22 \mathrm{a}$ & $21.22 b$ & 21.72 bc & 01.00 \\
\hline $15 \mathrm{~kg} \mathrm{P} \mathrm{P}_{2} \mathrm{O}_{5}+$ inoc. & $22.73 \mathrm{a}$ & $23.02 \mathrm{a}$ & $22.87 \mathrm{a}$ & -0.29 & $22.86 \mathrm{a}$ & $22.99 \mathrm{a}$ & $22.93 \mathrm{a}$ & -0.06 \\
\hline $\begin{array}{c}15 \mathrm{~kg} \mathrm{P}_{2} \mathrm{O}_{5}+\text { inoc. }+ \\
\text { cyano }\end{array}$ & $21.24 \mathrm{a}$ & $19.50 \mathrm{~b}$ & $20.37 b$ & 1.74 & $21.90 \mathrm{a}$ & $19.93 \mathrm{~b}$ & $20.91 \mathrm{c}$ & 1.97 \\
\hline Mean & 21.61 & 21.32 & & & 22.34 & 21.75 & & \\
\hline F. test & & \multicolumn{2}{|c|}{ L.S.D. 0.05} & L.S.D. 0.01 & & \multicolumn{2}{|c|}{ L.S.D. 0.05} & L.S.D. 0.01 \\
\hline $\begin{array}{c}A \\
B \\
A B\end{array}$ & $\begin{array}{l}\text { NS } \\
\star \\
\text { NS }\end{array}$ & \multicolumn{2}{|c|}{$\begin{array}{c}- \\
2.14\end{array}$} & $\begin{array}{l}- \\
- \\
-\end{array}$ & $\begin{array}{l}\text { NS } \\
\star \star \\
\text { NS }\end{array}$ & \multicolumn{2}{|c|}{$\begin{array}{c}- \\
1.077 \\
-\end{array}$} & $\begin{array}{c}- \\
1.48 \\
-\end{array}$ \\
\hline
\end{tabular}


Table 6 : Phosphorus \% and phosphorus content $\mathrm{kg} \mathrm{fed}^{-1}$ of faba bean seeds as affected by furrow spacing and phosphorus treatments

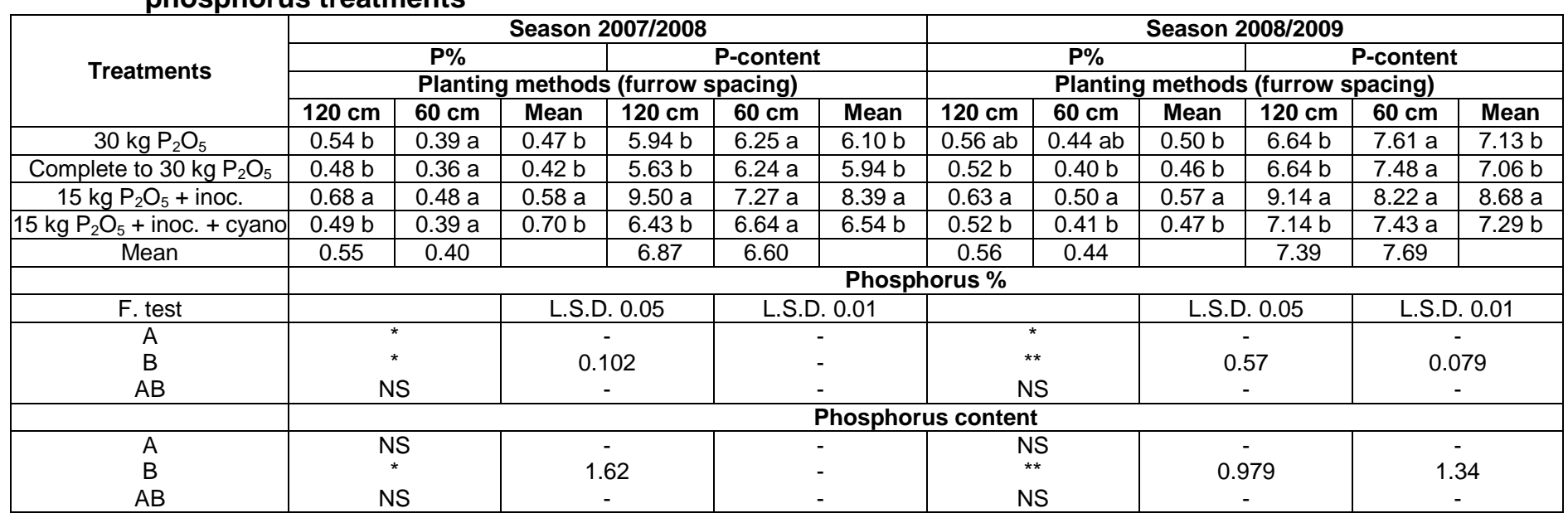

Table 7:Residual available $\mathrm{N}$ and $\mathrm{P}$ in the soil $\mathrm{mg} \mathrm{kg}^{-1}$ after faba bean harvesting

\begin{tabular}{|c|c|c|c|c|c|c|c|c|c|c|c|c|}
\hline \multirow{4}{*}{ Treatments } & \multicolumn{6}{|c|}{ Season $2007 / 2008$} & \multicolumn{6}{|c|}{ Season 2008/2009 } \\
\hline & \multicolumn{3}{|c|}{ Available N } & \multicolumn{3}{|c|}{ Available P } & \multicolumn{3}{|c|}{ Available N } & \multicolumn{3}{|c|}{ Available $\mathbf{P}$} \\
\hline & \multicolumn{6}{|c|}{ Planting methods (furrow spacing) } & \multicolumn{6}{|c|}{ Planting methods (furrow spacing) } \\
\hline & $120 \mathrm{~cm}$ & $60 \mathrm{~cm}$ & Mean & $120 \mathrm{~cm}$ & $60 \mathrm{~cm}$ & Mean & $120 \mathrm{~cm}$ & $60 \mathrm{~cm}$ & Mean. & $120 \mathrm{~cm}$ & $60 \mathrm{~cm}$ & Mean \\
\hline $30 \mathrm{~kg} \mathrm{P}_{2} \mathrm{O}_{5}$ & $26.25 \mathrm{a}$ & $22.75 \mathrm{~b}$ & $24.50 \mathrm{~b}$ & $16.25 \mathrm{a}$ & $17.40 \mathrm{a}$ & 16.83 & $27.13 \mathrm{a}$ & $22.75 \mathrm{~b}$ & $24.94 \mathrm{~b}$ & $16.60 \mathrm{a}$ & $16.80 \mathrm{a}$ & 16.70 \\
\hline Complete to $30 \mathrm{~kg} \mathrm{P}_{2} \mathrm{O}_{5}$ & $25.25 \mathrm{a}$ & $35.00 \mathrm{a}$ & $30.13 a$ & $16.00 \mathrm{a}$ & $15.50 \mathrm{a}$ & 15.75 & $26.25 \mathrm{a}$ & $33.25 \mathrm{a}$ & $29.75 a$ & $15.70 \mathrm{~b}$ & $13.80 \mathrm{~b}$ & 14.75 \\
\hline $15 \mathrm{~kg} \mathrm{P}_{2} \mathrm{O}_{5}+$ inoc. & $21.00 \mathrm{a}$ & $22.75 \mathrm{~b}$ & $21.88 \mathrm{~b}$ & $15.40 \mathrm{a}$ & $16.80 \mathrm{a}$ & 16.10 & $26.25 \mathrm{a}$ & $25.38 \mathrm{~b}$ & $25.82 \mathrm{~b}$ & $14.3 \mathrm{bc}$ & $16.00 \mathrm{a}$ & 15.15 \\
\hline $15 \mathrm{~kg} \mathrm{P}_{2} \mathrm{O}_{5}+$ inoc. + cyano & $22.75 \mathrm{a}$ & $28.00 \mathrm{~b}$ & $25.38 \mathrm{~b}$ & $13.20 \mathrm{a}$ & $13.00 \mathrm{~b}$ & 13.10 & $28.00 \mathrm{a}$ & $29.75 \mathrm{a}$ & $28.88 \mathrm{a}$ & $12.80 \mathrm{c}$ & $14.30 \mathrm{a}$ & 13.55 \\
\hline \multirow[t]{2}{*}{ Mean } & 23.81 & 27.13 & & 15.21 & 15.68 & & 26.91 & 27.78 & & 14.85 & 15.23 & \\
\hline & \multicolumn{12}{|c|}{ Available N } \\
\hline F. test & \multicolumn{4}{|c|}{ L.S.D. 0.05} & \multicolumn{2}{|c|}{ L.S.D. 0.01} & & & \multicolumn{2}{|c|}{ L.S.D. 0.05} & \multicolumn{2}{|c|}{ L.S.D. 0.01} \\
\hline $\begin{array}{c}\mathrm{A} \\
\mathrm{B} \\
\mathrm{AB}\end{array}$ & \multicolumn{2}{|c|}{$\begin{array}{c}\text { NS } \\
* * \\
*\end{array}$} & \multicolumn{2}{|c|}{$\begin{array}{c}- \\
4.98 \\
5.98\end{array}$} & \multicolumn{2}{|c|}{$\overline{8} \overline{19}$} & \multicolumn{2}{|c|}{$\begin{array}{c}\text { NS } \\
* * \\
*\end{array}$} & \multicolumn{2}{|c|}{$\begin{array}{c}- \\
2.69 \\
3.80\end{array}$} & \multicolumn{2}{|c|}{$\begin{array}{c}- \\
5.21\end{array}$} \\
\hline & \multicolumn{12}{|c|}{ Available P } \\
\hline $\begin{array}{c}A \\
B \\
A B\end{array}$ & \multicolumn{2}{|c|}{$\begin{array}{l}\text { NS } \\
\star \\
\text { NS }\end{array}$} & \multicolumn{2}{|c|}{$\begin{array}{c}7.4 \\
-\end{array}$} & \multicolumn{2}{|c|}{ - } & \multicolumn{2}{|c|}{ ** } & \multicolumn{2}{|c|}{$\begin{array}{c}- \\
2.67 \\
2.78\end{array}$} & \multicolumn{2}{|c|}{$\begin{array}{c}5.17 \\
-\end{array}$} \\
\hline
\end{tabular}

